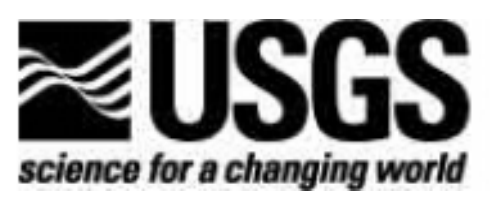

\title{
Coastal Vulnerability Assessment of Point Reyes National Seashore to Sea-Level Rise
}

By Elizabeth A. Pendleton, E. Robert Thieler, and S. Jeffress Williams

Any use of trade, firm, or product names is for descriptive purposes only and does not imply endorsement by the U.S. Government

\section{Open-File Report 2005-1059}

U.S. Department of the Interior U.S. Geological Survey 


\title{
U.S. Department of the Interior \\ Gale A. Norton, Secretary
}

\section{U.S. Geological Survey \\ P. Patrick Leahy, Acting Director}

\author{
U.S. Geological Survey, Reston, Virginia
}

For Additional Information:

See the National Park Unit Coastal Vulnerability study at http://woodshole.er.usgs.gov/project-pages/nps-cvi/, the National Coastal Vulnerability study at http://woodshole.er.usgs.gov/project-pages/cvi/, or view the USGS online fact sheet for this project in PDF format at http://pubs.usgs.gov/fs/fs095-02/.

To visit Point Reyes National Seashore Web site go to http://www.nps.gov/pore/index.htm.

\section{Contact:}

Elizabeth A. Pendleton, E. Robert Thieler, S. Jeffress Williams

U.S. Geological Survey

384 Woods Hole Road

Woods Hole, MA 02543

ependleton@usgs.gov, rthieler@usgs.gov, jwilliams@usgs.gov

Telephone: $508-457-2259$ or $508-548-8700$

Rebecca Beavers

National Park Service

Natural Resource Program Center

Geologic Resources Division

P.O. Box 25287

Denver, CO 80225-0287

Rebecca_Beavers@nps.gov

Telephone: 303-987-6945

For product and ordering information:

World Wide Web: http://www.usgs.gov/pubprod

Telephone: 1-888-ASK-USGS

For more information on the USGS - the Federal source for science about the Earth, its natural and living resources, natural hazards, and the environment:

World Wide Web: http://www.usgs.gov

Telephone: 1-888-ASK-USGS

Although this report is in the public domain, permission must be secured from the individual copyright owners to reproduce any copyrighted material contained within this report. 


\section{Contents}

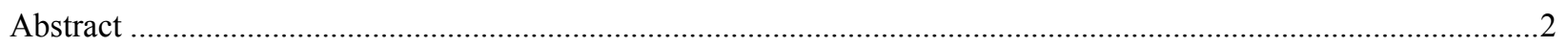

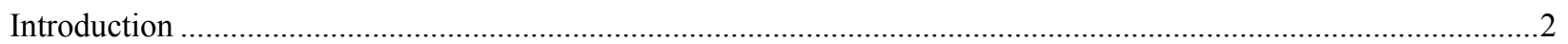

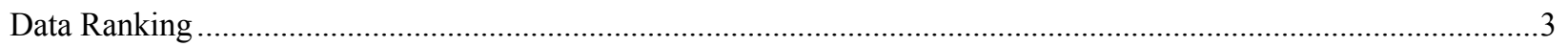

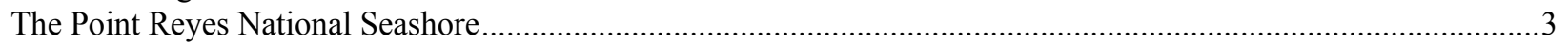

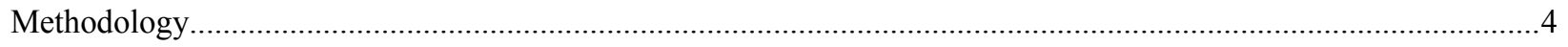

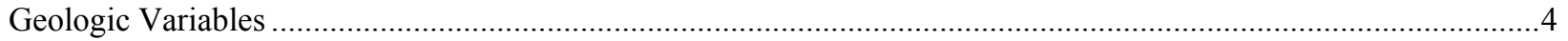

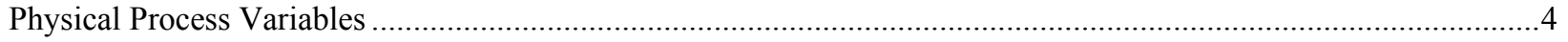

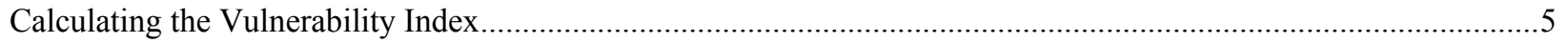

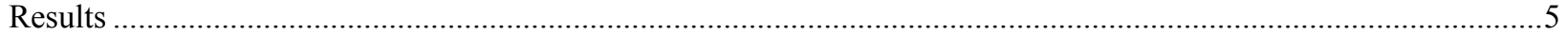

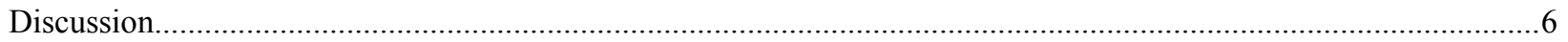

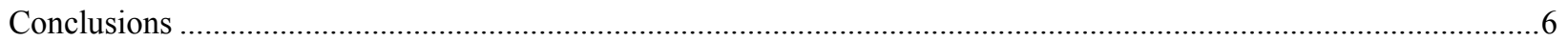

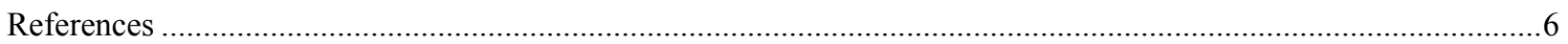

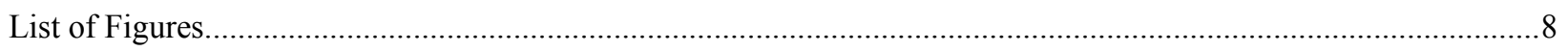

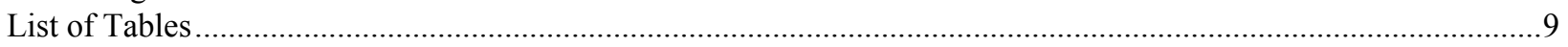




\title{
Coastal Vulnerability Assessment of Point Reyes National Seashore (PORE) to Sea- Level Rise
}

\author{
By Elizabeth A. Pendleton, E. Robert Thieler, S. and Jeffress Williams
}

\section{Abstract}

A coastal vulnerability index (CVI) was used to map the relative vulnerability of the coast to future sealevel rise within Point Reyes National Seashore in Northern California. The CVI ranks the following in terms of their physical contribution to sea-level rise-related coastal change: geomorphology, regional coastal slope, rate of relative sea-level rise, historical shoreline change rates, mean tidal range and mean significant wave height. The rankings for each input variable were combined and an index value calculated for 1-minute grid cells covering the park. The CVI highlights those regions where the physical effects of sea-level rise might be the greatest. This approach combines the coastal system's susceptibility to change with its natural ability to adapt to changing environmental conditions, yielding a quantitative, although relative, measure of the park's natural vulnerability to the effects of sea-level rise. The CVI provides an objective technique for evaluation and long-term planning by scientists and park managers. Point Reyes National Seashore consists of sand and gravel beaches, rock cliffs, sand dune cliffs, and pocket beaches. The areas within Point Reyes that are likely to be most vulnerable to sea-level rise are areas of unconsolidated sediment where the coastal slope is lowest and wave energy is high.

\section{Introduction}

The National Park Service (NPS) is responsible for managing 12,000 kilometers (7,500 miles) of shoreline along oceans and lakes. In 2001, the U.S. Geological Survey (USGS), in partnership with the (NPS) Geologic Resources Division, began conducting hazard assessments of future sea-level change by creating maps to assist NPS in managing its valuable coastal resources. This report presents the results of a vulnerability assessment for Point Reyes National Seashore, highlighting areas that are likely to be most affected by future sea-level rise.

Global sea level has risen approximately 18 centimeters (7.1 inches) in the past century (Douglas, 1997). Climate models predict an additional rise of $48 \mathrm{~cm}$ (18.9 in.) by 2100 (IPCC, 2001), which is more than double the rate of rise for the 20th century. Potential coastal impacts of sea-level rise include shoreline erosion, saltwater intrusion into groundwater aquifers, inundation of wetlands and estuaries, and threats to cultural and historic resources as well as infrastructure. Predicted accelerated global sea-level rise has generated a need in coastal geology to determine the likely response of a coastline to sea-level rise. However, an accurate and quantitative approach to predicting coastal change is difficult to establish. Even the kinds of data necessary to predict shoreline response are the subject of scientific debate. A number of predictive approaches have been proposed (National Research Council, 1990 and 1995), including: 1, extrapolation of historical data (for example, coastal erosion rates); 2, static inundation modeling; 3, application of a simple geometric model (for example, the Bruun Rule); 4, application of a sediment dynamics/budget model; or 5, Monte Carlo (probabilistic) simulation based on parameterized physical forcing variables. However, each of these approaches has inadequacies or can be invalid for certain applications (National Research Council, 1990). Additionally, shoreline response to sea-level change is further complicated by human modification of the natural coast such as beach nourishment projects, and engineered structures such as seawalls, revetments, groins, and jetties. Understanding how a natural or modified coast will respond to sea-level change is essential to preserving vulnerable coastal resources.

The primary challenge in predicting shoreline response to sea-level rise is to quantify the variables that contribute to coastal evolution in a given area. In order to address the multi-faceted task of predicting sea-level rise impact, the USGS has implemented a methodology to identify areas that may be most vulnerable to future sea-level 
rise (see Hammar-Klose and Thieler, 2001). This technique uses different ranges of vulnerability (low to very high) to describe a coast's susceptibility to physical change as sea level rises. The vulnerability index determined here focuses on six variables that strongly influence coastal evolution:

1. Geomorphology

2. Historical shoreline change rate

3. Regional coastal slope

4. Relative sea-level change

5. Mean significant wave height

6. Tidal range

These variables can be divided into two groups: 1 , geologic variables and 2 , physical process variables. The geologic variables are geomorphology, historic shoreline change rate, and coastal slope; they account for a shoreline's relative resistance to erosion, long-term erosion/accretion trend, and its susceptibility to flooding, respectively. The physical process variables include significant wave height, tidal range, and sea-level change, all of which contribute to the inundation hazards of a particular section of coastline over time scales from hours to centuries. A relatively simple vulnerability ranking system (Table 1) allows the six variables to be incorporated into an equation that produces a coastal vulnerability index (CVI). The CVI can be used by scientists and park managers to evaluate the likelihood that physical change may occur along a shoreline as sea level continues to rise.

Additionally, (NPS) staff will be able to incorporate information provided by this vulnerability assessment technique into general management plans.

\section{Data Ranking}

Table 1 shows the six variables described in the Introduction, which include both quantitative and qualitative information. The five quantitative variables are assigned a vulnerability ranking based on their actual values, whereas the non-numerical geomorphology variable is ranked qualitatively according to the relative resistance of a given landform to erosion. Shorelines with erosion/accretion rates between -1.0 and $+1.0 \mathrm{~m} / \mathrm{yr}$ are ranked as being of moderate vulnerability in terms of that particular variable. Increasingly higher erosion or accretion rates are ranked as correspondingly higher or lower vulnerability. Regional coastal slopes range from very high vulnerability, $<4.59$ percent, to very low vulnerability at values $>14.7$ percent. The rate of relative sea-level change is ranked using the modern rate of eustatic rise $(1.8 \mathrm{~mm} / \mathrm{yr})$ as very low vulnerability. Since this is a global or "background" rate common to all shorelines, the sea-level rise ranking reflects primarily local to regional isostatic or tectonic adjustment. Mean wave height contributions to vulnerability range from very low $(<1.1 \mathrm{~m})$ to very high $(>2.6 \mathrm{~m})$. Tidal range is ranked such that microtidal $(<1 \mathrm{~m})$ coasts are very high vulnerability, and macrotidal $(>6 \mathrm{~m})$ coasts are very low vulnerability.

\section{The Point Reyes National Seashore}

The sandy beaches and cliffed shores of Point Reyes National Seashore lie along the Northern Coast of California (Figure 1). Point Reyes and the neighboring San Francisco Bay Area are among the most complex and active geologic settings in the world (for more information on the geology of the San Francisco Bay region see: http://wrgis.wr.usgs.gov/wgmt/sfbay/index.html). Point Reyes National Seashore differs geologically from adjacent land in Marin County because the rocks composing Point Reyes Peninsula have traveled northwestward from Monterey Bay over the past 15 million years via the San Andreas and San Gregorio Faults (Galloway, 1977; Clark and Brabb, 1997) (Figure 2). Prior to this $150 \mathrm{~km}$ voyage, it is thought that Point Reyes Peninsula arrived in Monterey as an exotic terrane around 60 million years ago, then remained docked for over 40 million years before being carried up the coast (Locke, 1994;Clark and Brabb, 1997). The plate motion that pushes Point Reyes Peninsula to the northwest happens episodically. In 1906 a magnitude 7.7 earthquake (Waldo and others, 1993) shook San Francisco causing Point Reyes Peninsula to travel 20 feet to the northwest along the San Andreas Fault. Other geologic hazards that can result in immediate and major coastal and sea-level change in this region include 
landslides and tsunamis, but they are not directly addressed in the methodology of this report because their occurrence is episodic and the coastal impacts are difficult to predict.

\section{Methodology}

In order to develop a database for a park-wide assessment of coastal vulnerability, data for each of the six variables mentioned above were gathered from state and federal agencies (Table 2). The database is based on that used by Thieler and Hammar-Klose (1999) and loosely follows an earlier database developed by Gornitz and White (1992). A comparable assessment of the sensitivity of the Canadian coast to sea-level rise is presented by Shaw and others (1998).

The database was constructed using a 1:24,000-scale shoreline for Point Reyes that was obtained from the California Spatial Information Library (http://gis.ca.gov/). Data for each of the six variables (geomorphology, shoreline change, coastal slope, relative sea-level rise, significant wave height, and tidal range) were added to the shoreline attribute table using a 1-minute (approximately $1.5 \mathrm{~km}$ ) grid (Figure 3). Next each variable in each grid cell was assigned a vulnerability value from 1-5 ( 1 is very low vulnerability, 5 is very high vulnerability) based on the potential magnitude of its contribution to physical changes on the coast as sea level rises (Table 1).

\section{Geologic Variables}

The geomorphology variable expresses the relative erodibility of different landform types (Table 1). These data were derived from oblique aerial photography of the California coast

(http://www.californiacoastline.org/). In addition, field visits were made within accessible locations of the park to verify the geomorphologic classification (Figure 4 A-J and Figure 5). Point Reyes contains areas of several different geomorphologic features, including low to very low vulnerability granitic, sandstone, and conglomerate cliffs, moderate vulnerability alluvium and beach and dune deposit bluffs, and high and very high vulnerability gravel and sand beaches and spits (Figure 5) (Galloway, 1977; Clark and Brabb, 1997).

Shoreline erosion and accretion rates for Point Reyes National Seashore were calculated from data provided by the USGS National Assessment of Coastal Change Hazards project (C.J. Hapke and others, written commun., 2004) (Table 2). Shoreline change (m/yr) was calculated at $50 \mathrm{~m}$ intervals (transects) along the coast using Digital Shoreline Analysis System (DSAS) software (http://woodshole.er.usgs.gov/project-pages/dsas/) to derive the rate of shoreline change from $1880-1998$. The change rates for each transect within a 1-minute grid cell were averaged to determine the shoreline change value used here, with positive numbers indicating accretion and negative numbers indicating erosion. Shoreline change rates within Point Reyes National Seashore all fell within +1 to $-1 \mathrm{~m} / \mathrm{yr}$ (moderate vulnerability) (Figure 6).

Regional coastal slope is an indication of the relative vulnerability to inundation and the potential rapidity of shoreline retreat because low-sloping coastal regions should retreat faster than steeper regions (Pilkey and Davis, 1987). The regional slope of the coastal zone was calculated from a grid of topographic and bathymetric elevations extending $10 \mathrm{~km}$ landward and seaward of the shoreline. Elevation data were obtained from the National Geophysical Data Center (NGDC) as gridded topographic and bathymetric elevations at 0.1 -meter vertical resolution for 90-meter grid cells. Regional coastal slopes for Point Reyes fell within the very low to very high vulnerability category $(<4.55 \%$ - $>14.7 \%)$ (Figure 7$)$.

\section{Physical Process Variables}

The relative sea-level change variable is derived from the change in annual mean water elevation over time as measured at tide gauge stations along the coast. The rate of sea-level rise for Point Reyes, CA is $2.51+/-1.27$ $\mathrm{mm} / \mathrm{yr}$ based on 25 years of data (Zervas, 2001). This variable inherently includes both eustatic sea-level rise as well as regional sea-level rise due to isostatic and tectonic adjustments of the land surface. Relative sea-level change data 
are a historical record, and thus portray only the recent sea-level trend ( $<150$ years). Relative sea-level rise for Point Reyes is moderate vulnerability based on water elevation data at Point Reyes, CA (Figure 8).

Mean significant wave height is used here as a proxy for wave energy which drives coastal sediment transport. Wave energy is directly related to the square of wave height:

$$
E=1 / 8 \rho g H^{2}
$$

where $E$ is energy density, $H$ is wave height, $\rho$ is water density and $g$ is acceleration due to gravity. Thus, the ability to mobilize and transport coastal sediments is a function of wave height squared. In this report, we use hindcast nearshore mean significant wave height data for the period 1956-75 obtained from the U.S. Army Corps of Engineers Wave Information Study (WIS) (See references in Hubertz and others, 1996). The model wave heights were compared to historical measured wave height data obtained from the NOAA National Data Buoy Center to ensure that model values were representative of the study area. For Point Reyes, mean significant wave heights are between 0.2 and $2.6 \mathrm{~m}$, which represents very low to very high vulnerability (Figure 9).

Tidal rangeis linked to both permanent and episodic inundation hazards. Tide range data were obtained from NOAA/NOS published benchmarks from Drakes Bay. Mean tidal range is $1.19 \mathrm{~m}$; therefore Point Reyes was classified as high vulnerability (1.0-2.0 m) with respect to tidal range (Figure 10).

\section{Calculating the Vulnerability Index}

The coastal vulnerability index (CVI) presented here is the same as that used in Thieler and Hammar-Klose (1999) and is similar to that used in Gornitz and others (1994), as well as to the sensitivity index employed by Shaw and others (1998). The (CVI) allows the six variables to be related in a quantifiable manner that expresses the relative vulnerability of the coast to physical changes due to future sea-level rise. This method yields numerical data that cannot be equated directly with particular physical effects. It does, however, highlight areas where the various effects of sea-level rise may be the greatest. Once each section of coastline is assigned a vulnerability value for each specific data variable, the coastal vulnerability index (CVI) is calculated as the square root of the product of the ranked variables divided by the total number of variables;

$$
\mathrm{CVI}=\sqrt{\frac{\left(a^{*} b^{*} c^{*} d^{*} e^{*} f\right)}{6}}
$$

where, $\mathrm{a}=$ geomorphology, $\mathrm{b}=$ shoreline erosion/accretion rate, $\mathrm{c}=$ coastal slope, $\mathrm{d}=$ relative sea-level change rate, $\mathrm{e}=$ mean significant wave height, and $\mathrm{f}=$ mean tide range. The calculated (CVI) value is then divided into quartile ranges to highlight different vulnerabilities within the park. The (CVI) ranges (low—very high) reported here apply specifically to Point Reyes National Seashore, and are not comparable to (CVI) ranges in other parks where the (CVI) has been employed (i.e. very high vulnerablity means the same among parks; it's the numeric values that differ, such that a numeric value that equals very high vulnerability in one park may equal moderate vulnerability in another). To compare vulnerability between coastal parks, the national-scale studies should be used (Thieler and Hammar-Klose, 1999, 2000a, and 2000b). We feel this approach best describes and highlights the vulnerability specific to each park.

\section{Results}

The CVI values calculated for Point Reyes range from 4.24 to 24.5 . The mean CVI value is 10.5 ; the mode is 6.0 and the median is 8.5. The standard deviation is 6.06. The 25th, 50th, and 75th percentiles are 6.0, 9.0 and 11.0 , respectively.

Figure 11 shows a map of the coastal vulnerability index for Point Reyes National Seashore. The CVI scores are divided into low, moderate, high, and very high-vulnerability categories based on the quartile ranges and visual inspection of the data. CVI values below 6.0 are assigned to the low vulnerability category. Values from 6.0 to 9.0 are considered moderate vulnerability. High-vulnerability values lie between 9.01 and 11.0. CVI values 
above 11.0 are classified as very high vulnerability. Figure 12 shows the percentage of Point Reyes shoreline in each vulnerability category. Over $90 \mathrm{~km}$ (50 miles) of shoreline is evaluated along the national seashore. Of this total, twenty-four percent of the mapped shoreline is classified as being at very high vulnerability due to future sea-level rise. Twenty-six percent is classified as high vulnerability, twenty-six percent as moderate vulnerability, and twentyfour percent as low vulnerability.

\section{Discussion}

The data within the coastal vulnerability index (CVI) show variability at different spatial scales (Figure 11). The ranked values for the physical process variables vary less than the geologic variables. The relative sea-level rise variable is constant at moderate vulnerability, and the tidal range variable is constant at high vulnerability. The significant wave height vulnerability is very low to very high because Point Reyes National Seashore contains both wave-sheltered and wave-exposed stretches of shoreline. The geologic variables show the most variability and thus have the most influence on the CVI (Figure 11). Geomorphologic features in the park include very high vulnerability sandy beaches, high vulnerability gravel and cobble beaches, moderate vulnerability alluvium and coastal bluffs, and low to very low vulnerability rocks and cliffs (Figure 4 A-J and Figure 5). Vulnerability assessment based on shoreline change is constant at moderate vulnerability (Figure 6), but regional coastal slope is in the low to very high vulnerability range.

The most influential variables in the CVI are geomorphology, coastal slope, and mean significant wave height; therefore they may be considered the dominant factors controlling how Point Reyes will evolve as sea level rises.

\section{Conclusions}

The coastal vulnerability index (CVI) provides insight into the relative potential of coastal change due to future sea-level rise. The maps and data presented here can be viewed in at least two ways:

1) as an indication of where physical changes are most likely to occur as sea level continues to rise; and

2) as a planning tool for the Point Reyes National Seashore.

As ranked in this study, geomorphology, regional coastal slope, and wave energy are the most important variables in determining the CVI for Point Reyes National Seashore. Tidal range, shoreline change, and rate of sealevel rise do not contribute to the variability in the coastal vulnerability index.

Point Reyes National Seashore preserves a dynamic natural environment, which must be understood in order to be managed properly. The CVI is one way that park managers can assess objectively the natural factors that contribute to the evolution of the coastal zone, and thus how the park may evolve in the future.

\section{References}

Clark, J.C. and Brabb, E. B., 1997, Geology of Point Reyes National Seashore and vicinity, California; A digital database: U.S. Geological Survey Open-File Report 1997-456.

Douglas, B.C., 1997, Global sea rise, a redetermination: Surveys in Geophysics, v. 18, p. 279-292.

Galloway, A., 1977, Geology of the Point Reyes Peninsula, Marin County, California: Bulletin 202, California Division of Mines and Geology, Sacramento, California, $72 \mathrm{p}$.

Gornitz, V. and White, T.W. 1992, A coastal hazards database for the U.S. West Coast: ORNL/CDIAC-81, NDP043C, Oak Ridge National Laboratory, Oak Ridge, Tenn.

Gornitz, V.M., Daniels, R.C., White, T.W., and Birdwell, K.R., 1994, The development of a coastal vulnerability assessment database, vulnerability to sea-level rise in the U.S. Southeast: Journal of Coastal Research, Special Issue No. 12, p. 327-338. 
Hammar-Klose, E.S., and Thieler, E.R., 2001, Coastal vulnerability to sea-Level rise, A Preliminary database for the U.S. Atlantic, Pacific, and Gulf of Mexico Coasts: U.S. Geological Survey, Digital Data Series, DDS-68, CDROM.

Hubertz, J.M., Thompson, E.F., and Wang, H.V., 1996, Wave information studies of U.S. coastlines; annotated bibliography on coastal and ocean data assimilation: U.S. Army Engineer Waterways Experiment Station, WIS Report 36, Vicksburg, 31 p.

IPCC, 2001, Climate change 2001, The scientific basis; contribution of working group I to the third assessment report of the intergovernmental panel on climate change: IPCC: Geneva, Switzerland, 563 p. (Also available on the web at www.ipcc.ch)

Locke, J., 1994, Geology of the Pt. Reyes Peninsula, College of Marin, 1 Dec 1994; last accessed 27 Feb 2006. http://www.marin.cc.ca.us/ jim/ring/ptreyes/ptrey1.htmINational Research Council, 1990, Managing coastal erosion, Washington: National Academy Press, $163 \mathrm{p}$.

National Research Council, 1995, Beach nourishment and protection, Washington: National Academy Press, 334 p.

Pilkey, O.H., and Davis, T.W., 1987, An analysis of coastal recession models, North Carolina coast, in D. Nummedal, O.H. Pilkey and J.D. Howard, eds., Sea-level fluctuation and coastal evolution: SEPM (Society for Sedimentary Geology) Special Publications No. 41, Tulsa, Okla., p. 59-68.

Shaw, J., Taylor, R.B., Forbes, D.L., Ruz, M.H., and Solomon, S., 1998, Sensitivity of the Canadian coast to sea-level rise: Geological Survey of Canada Bulletin 505, $114 \mathrm{p}$.

Thieler, E.R., and Hammar-Klose, E.S., 1999, National assessment of coastal vulnerability to sea-level rise, U.S. Atlantic Coast: U.S. Geological Survey Open-File Report 99-593, 1 sheet.

Thieler, E.R., and Hammar-Klose, E.S., 2000a, National assessment of coastal vulnerability to sea-level rise, U.S. Pacific Coast: U.S. Geological Survey Open-File Report 00-178, 1 sheet.

Thieler, E.R., and Hammar-Klose, E.S., 2000b, National assessment of coastal vulnerability to sea-level rise, U.S. Gulf of Mexico Coast: U.S. Geological Survey Open-File Report 00-179, 1 sheet.

Waldo, D.J., Kanamori, H., and Helmberger, D.V., 1993, Source study of the 1906 San Francisco earthquake. Bull. Seism. Soc. Am., vol. 83, pp. 981-1019.

Wolverton, R., and Wolverton, W., 1988, The national seashores; the complete guide to American's scenic coastal parks: Woodbine House, Inc., USA, 289 p.

Zervas, C., 2001, Sea level variations of the United States 1854-1999: NOAA Technical Report NOS CO-OPS 36 , 201 p. 


\section{List of Figures}

Figure 1. Location of Point Reyes National Seashore, Northern California.

Figure 2. Landsat TM satellite imagery of the San Francisco Bay Area showing major faults including the San Andreas and San Gregorio Faults (this figure courtesy of cooperative research and development between Pacific Gas \& Electric Company and the U.S. Geological Survey). http://www.sfbayquakes.org/mapview.html

Figure 3. Shoreline grid for Point Reyes National Seashore. Each cell is approximately 1-minute of shoreline and represents a shoreline segment for which each variable is defined.

Figure 4. Geomorphologic environments within Point Reyes National Seashore. The top figure provides an index for photos A-J

A) The photo was taken looking south toward Duxbury Point from the cliff at Palomarin Beach. The shore here is a sand beach backed by a poorly consolidated terrace deposit (moderate vulnerability). B) The photo was taken looking south from Limantour Beach (high vulnerability) toward Sculptured Beach (moderate vulnerability). C) A view looking south through Creamery Bay in a western arm of Drakes Estero. Limantour Spit (very high vulnerability) can be seen at the mouth of Drakes Estero. D) This photo was taken at Drakes Beach (moderate vulnerability) looking east toward the entrance to Drakes Estero. E) A pocket beach that is a popular haulout for seals and sea lions west of Chimney Rock, this shoreline is classified as low vulnerability because it is mostly rock cliffs, but there are interspersed pocket beaches. F) Low vulnerability rock cliffs adjacent to the G) pocket beach where the Historic Point Reyes Lifeboat Station is located. H) Very low vulnerability rock cliffs surrounding the Point Reyes Lighthouse. I) This is a view from the Lighthouse Visitor's Center looking Northeast toward Great Beach (moderate to high vulnerability). J) Point Reyes Beach South is classified as high vulnerability.

Figure 5. Coastal Geomorphology for Point Reyes National Seashore. The colored shoreline represents the variations in vulnerability associated with coastal geomorphology within the park. The very high vulnerability geomorphology is mostly low elevation sand beaches and estuary mouths. High vulnerability geomorphology includes gravel and cobble beaches or sand beaches backed by low dune cliffs. Moderate vulnerability geomorphology consists of alluvial fans and cliffs with sand beaches. Low vulnerability geomorphology includes medium cliffs with pocket beaches and rock platforms, and very low vulnerability areas consist of mostly high vertical rock cliffs.

Figure 6. Shoreline change rates for Point Reyes National Seashore. The colored shoreline represents the vulnerability associated with the rate of shoreline erosion or accretion. All of Point Reyes is moderate vulnerability ($1 \mathrm{~m} / \mathrm{yr}$ to $+1 \mathrm{~m} / \mathrm{yr}$ ) with respect to shoreline change.

Figure 7. Regional coastal slope for Point Reyes National Seashore. The colored shoreline represents the vulnerability associated with the regional slope of the land, $10 \mathrm{~km}$ landward and seaward of the shoreline. The highest vulnerability slopes are generally Drakes Estero and points north and west. Lower vulnerability slopes are generally adjacent to the mainland or near the higher mountains to the south.

Figure 8. Rate of relative sea-level rise for Point Reyes National Seashore. The colored shoreline represents the vulnerability associated with the rate of sea-level rise for Point Reyes, CA. All of Point Reyes is ranked as moderate vulnerability with respect to relative sea-level rise.

Figure 9. Mean Significant Wave Height for Point Reyes National Seashore. The colored shoreline represents the vulnerability associated with mean significant wave height within the park. Very High wave energy areas are located along the north side of Point Reyes where the dominant northwest waves approach. Wave heights are lowest in Tomales Bay and on the south side of Point Reyes.

Figure 10. Mean Tidal Range for Point Reyes National Seashore. The colored shoreline represents the vulnerability associated with mean tidal range for Point Reyes. All of Point Reyes is ranked as high vulnerability with respect to tidal range.

Figure 11: Relative Coastal Vulnerability for Point Reyes National Seashore. The colored shoreline represents the relative coastal vulnerability index $(\mathrm{CVI})$ determined from the six variables. The very high vulnerability shoreline is located along sandy beaches where significant wave heights are highest and regional coastal slope vulnerability is low. The lower vulnerability shoreline is located along rock cliffs where wave heights are lower and coastal slope is steep.

Figure 12: Percentage of Point Reyes shoreline in each CVI category. 


\section{List of Tables}

Table 1. Ranges for Vulnerability Ranking of Variables on the U.S. Pacific Coast.

Table 2. Sources of Data 


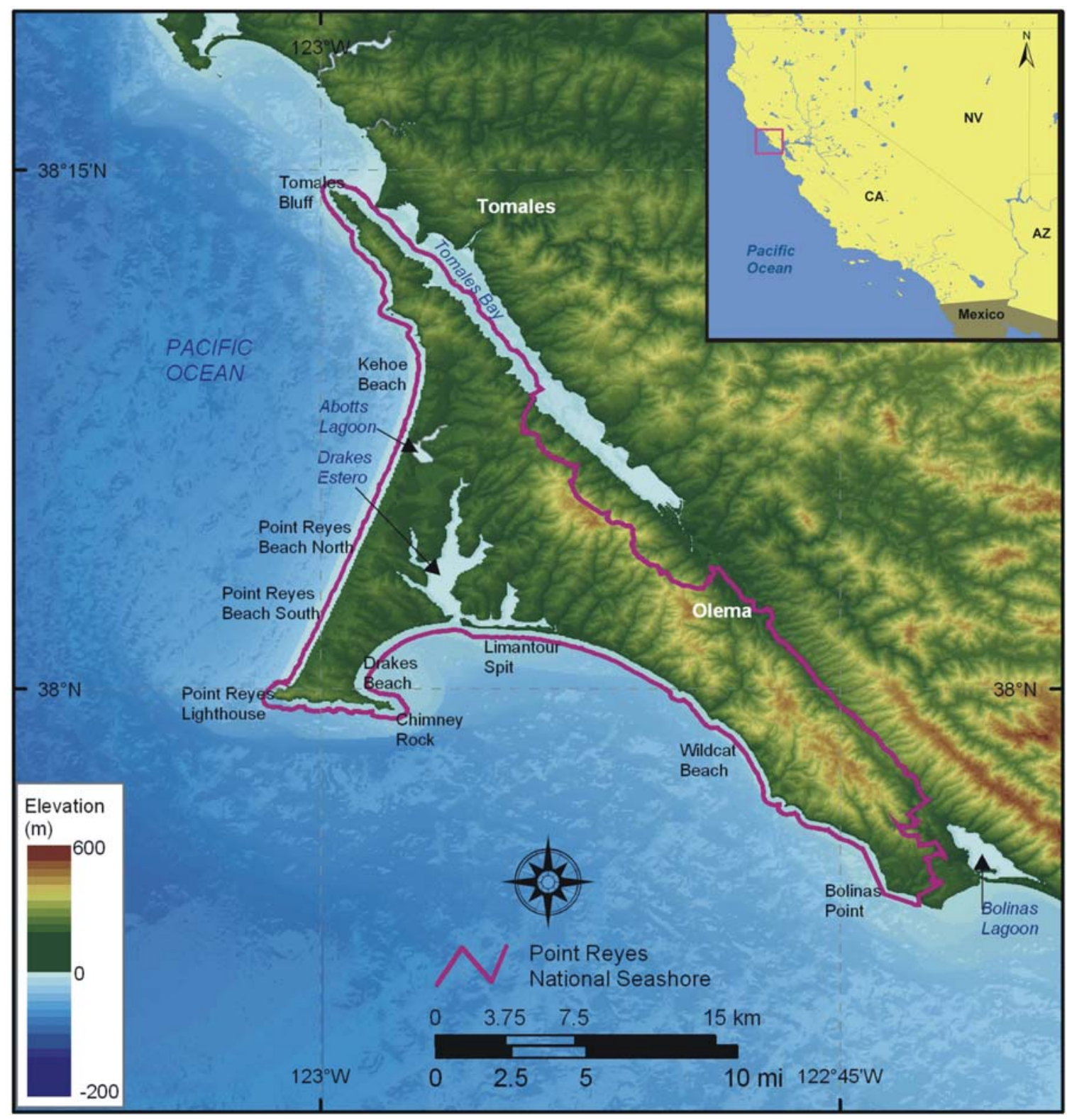

Figure 1. Location of Point Reyes National Seashore, Northern California. 


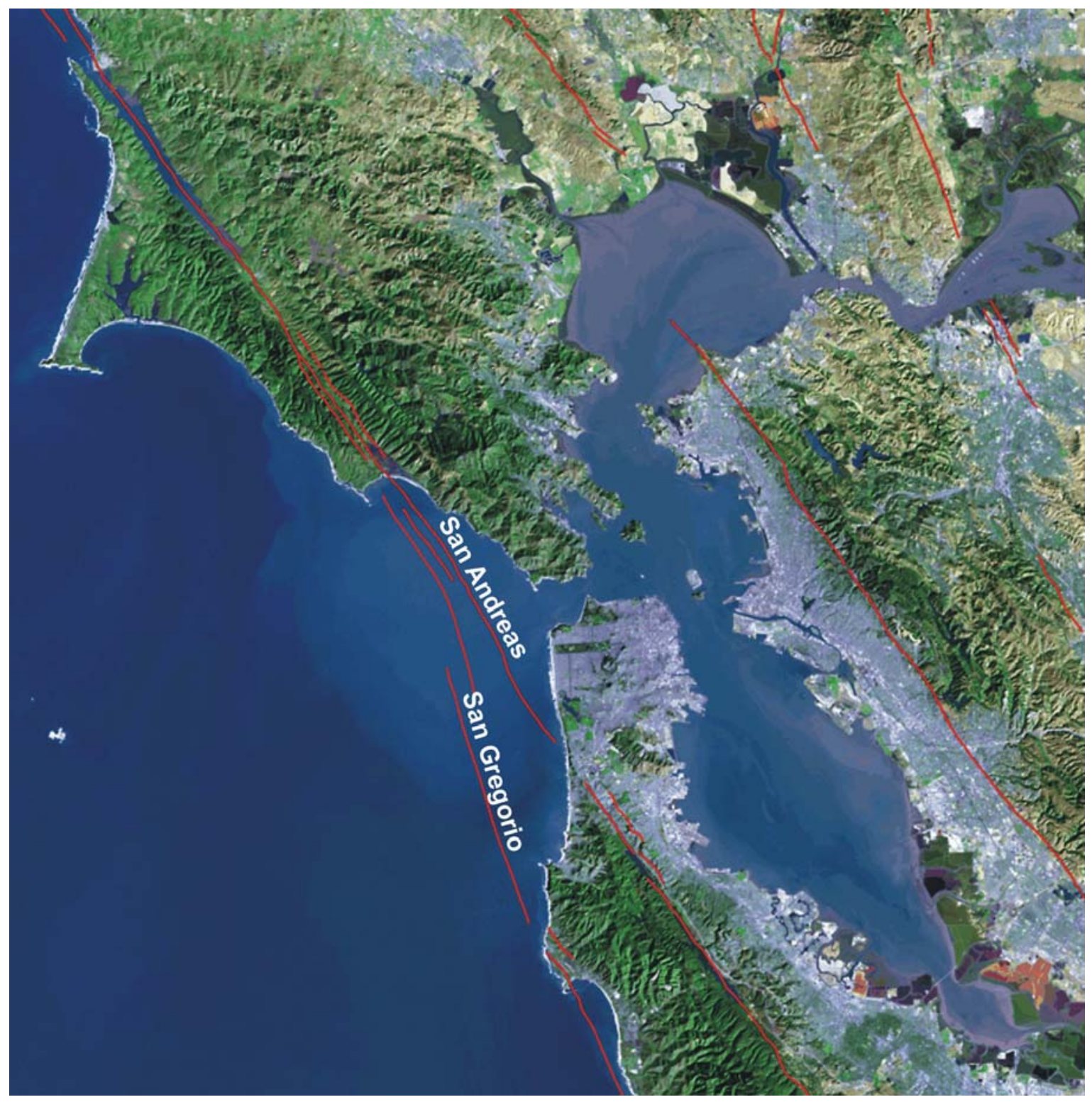

Figure 2. Landsat TM satellite imagery of the San Francisco Bay Area showing major faults including the San Andreas and San Gregorio Faults (this figure courtesy of cooperative research and development between Pacific Gas \& Electric Company and the U.S. Geological Survey). http://www.sfbayquakes.org/mapview.html. 


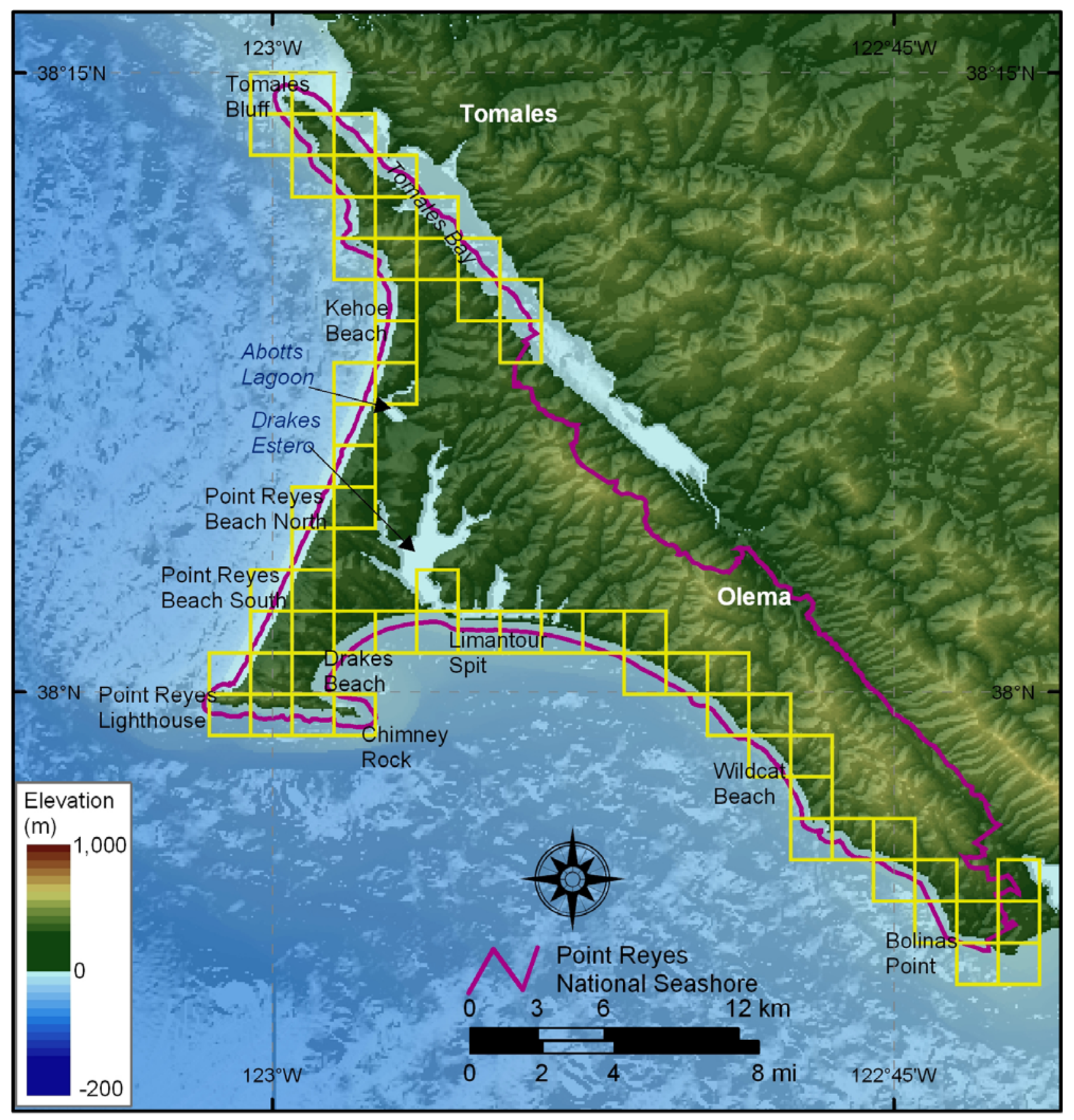

Figures 3. Shoreline grid for Point Reyes National Seashore. Each cell is approximately 1-minute of shoreline and represents a shoreline segment for which each variable is defined. 

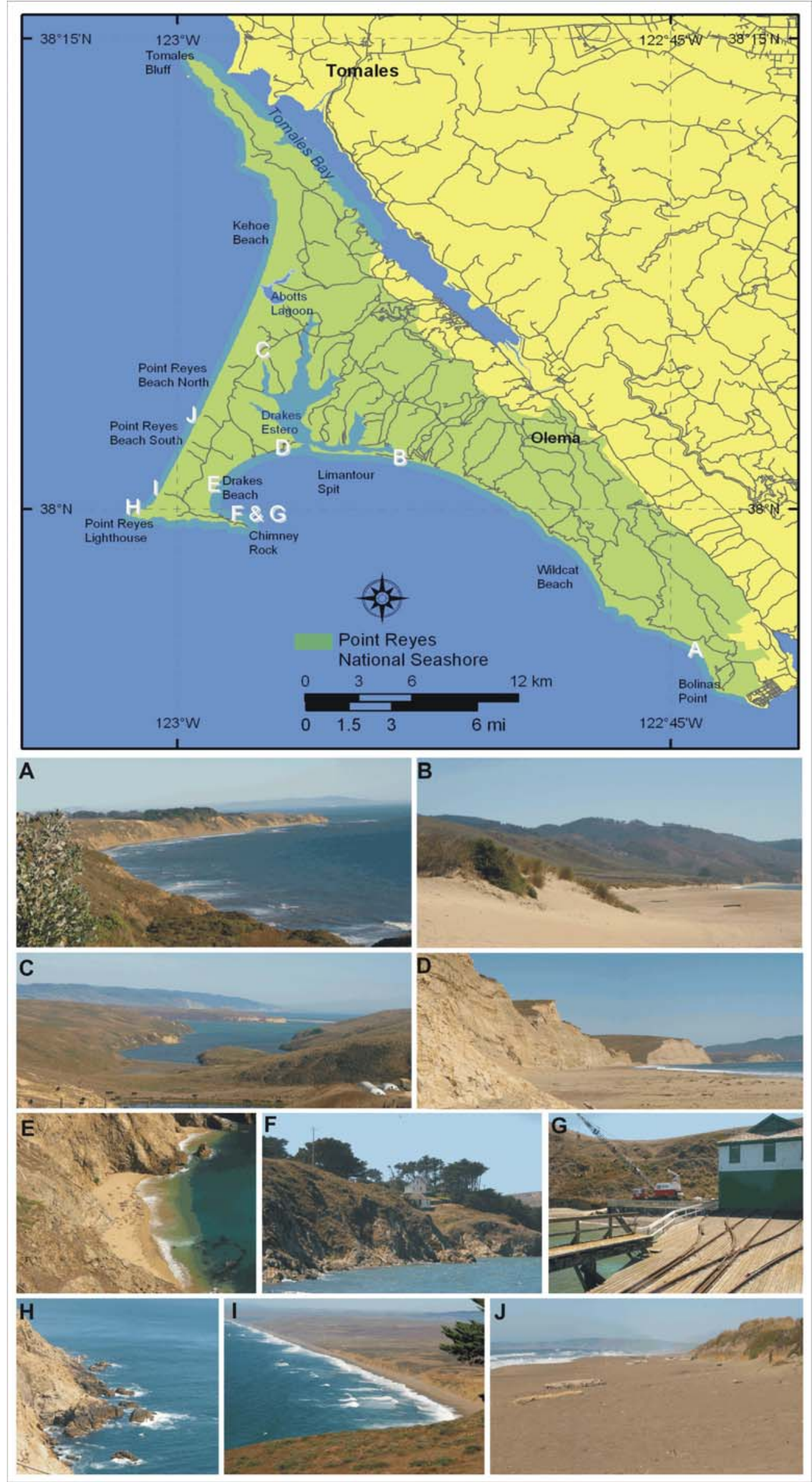
Figure 4. Geomorphologic environments within Point Reyes National Seashore. The top figure provides an index for photos A-J

A) The photo was taken looking south toward Duxbury Point from the cliff at Palomarin Beach. The shore here is a sand beach backed by a poorly consolidated terrace deposit (moderate vulnerability).

B) The photo was taken looking south from Limantour Beach (high vulnerability) toward Sculptured Beach (moderate vulnerability).

C) A view looking south through Creamery Bay in a western arm of Drakes Estero. Limantour Spit (very high vulnerability) can be seen at the mouth of Drakes Estero.

D) This photo was taken at Drakes Beach (moderate vulnerability) looking east toward the entrance to Drakes Estero.

E) A pocket beach that is a popular haulout for seals and sea lions west of Chimney Rock, this shoreline is classified as low vulnerability because it is mostly rock cliffs, but there are interspersed pocket beaches.

F) Low vulnerability rock cliffs adjacent to the

$\mathrm{G})$ pocket beach where the Historic Point Reyes Lifeboat Station is located.

H) Very low vulnerability rock cliffs surrounding the Point Reyes Lighthouse.

I) This is a view from the Lighthouse Visitor's Center looking Northeast toward Great Beach (moderate to high vulnerability).

J) Point Reyes Beach South is classified as high vulnerability. 


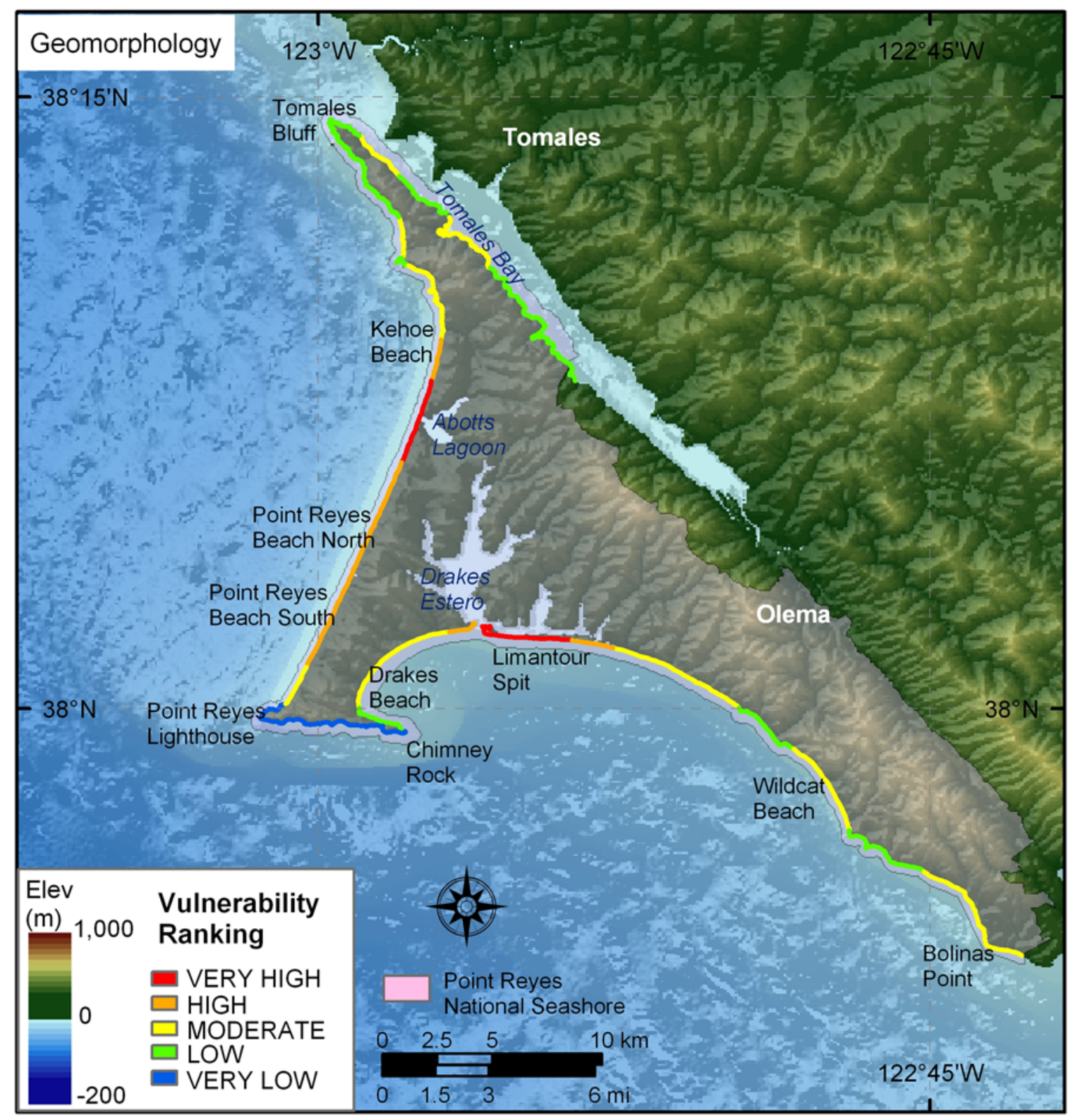

Figure 5. Coastal Geomorphology for Point Reyes National Seashore. The colored shoreline represents the variations in vulnerability associated with coastal geomorphology within the park. The very high vulnerability geomorphology is mostly low elevation sand beaches and estuary mouths. High vulnerability geomorphology includes gravel and cobble beaches or sand beaches backed by low dune cliffs. Moderate vulnerability geomorphology consists of alluvial fans and cliffs with sand beaches. Low vulnerability geomorphology includes medium cliffs with pocket beaches and rock platforms, and very low vulnerability areas consist of mostly high vertical rock cliffs. 


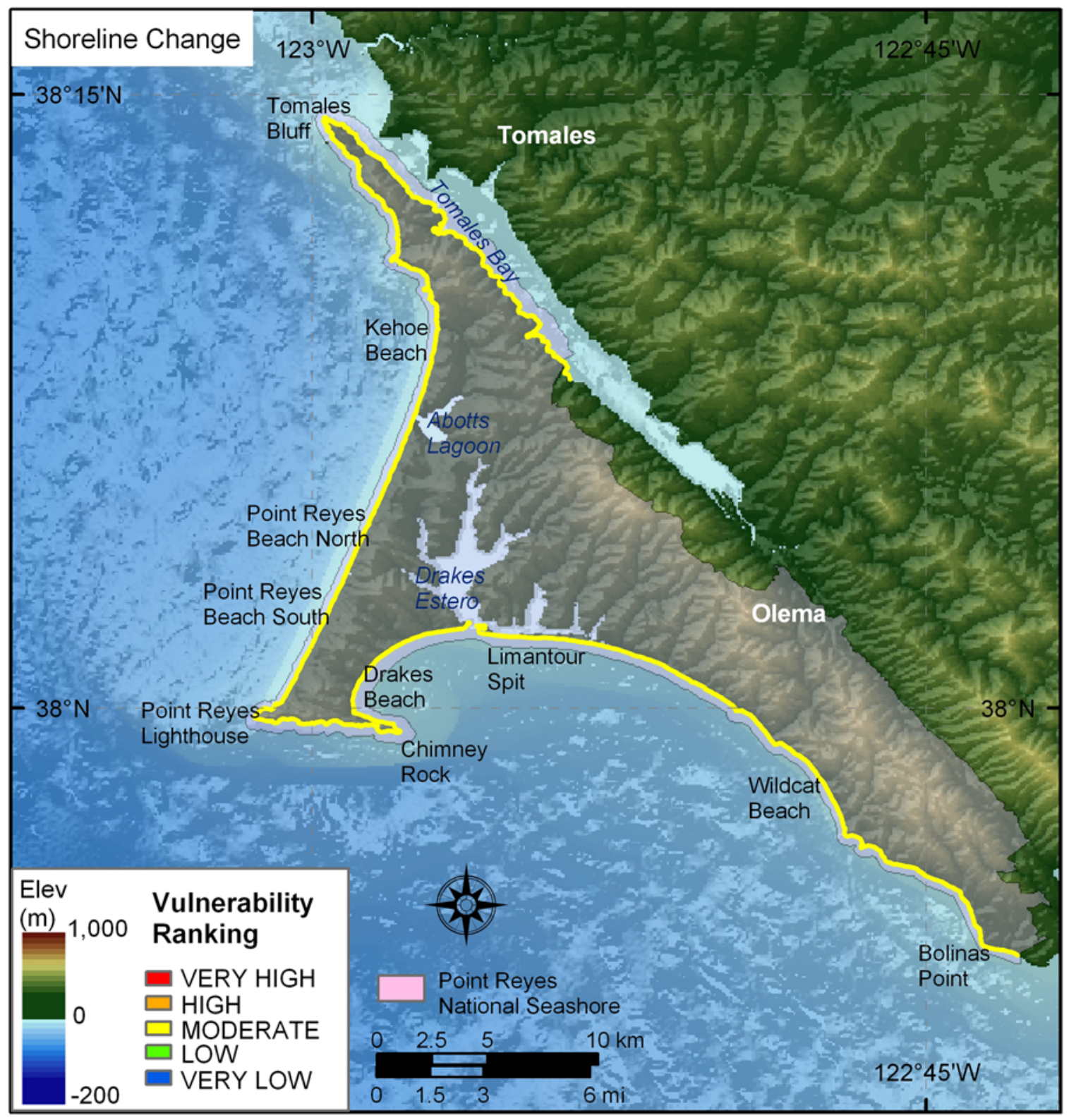

Figure 6. Shoreline change rates for Point Reyes National Seashore. The colored shoreline represents the vulnerability associated with the rate of shoreline erosion or accretion. All of Point Reyes is moderate vulnerability $(-1 \mathrm{~m} / \mathrm{yr}$ to $+1 \mathrm{~m} / \mathrm{yr})$ with respect to shoreline change. 


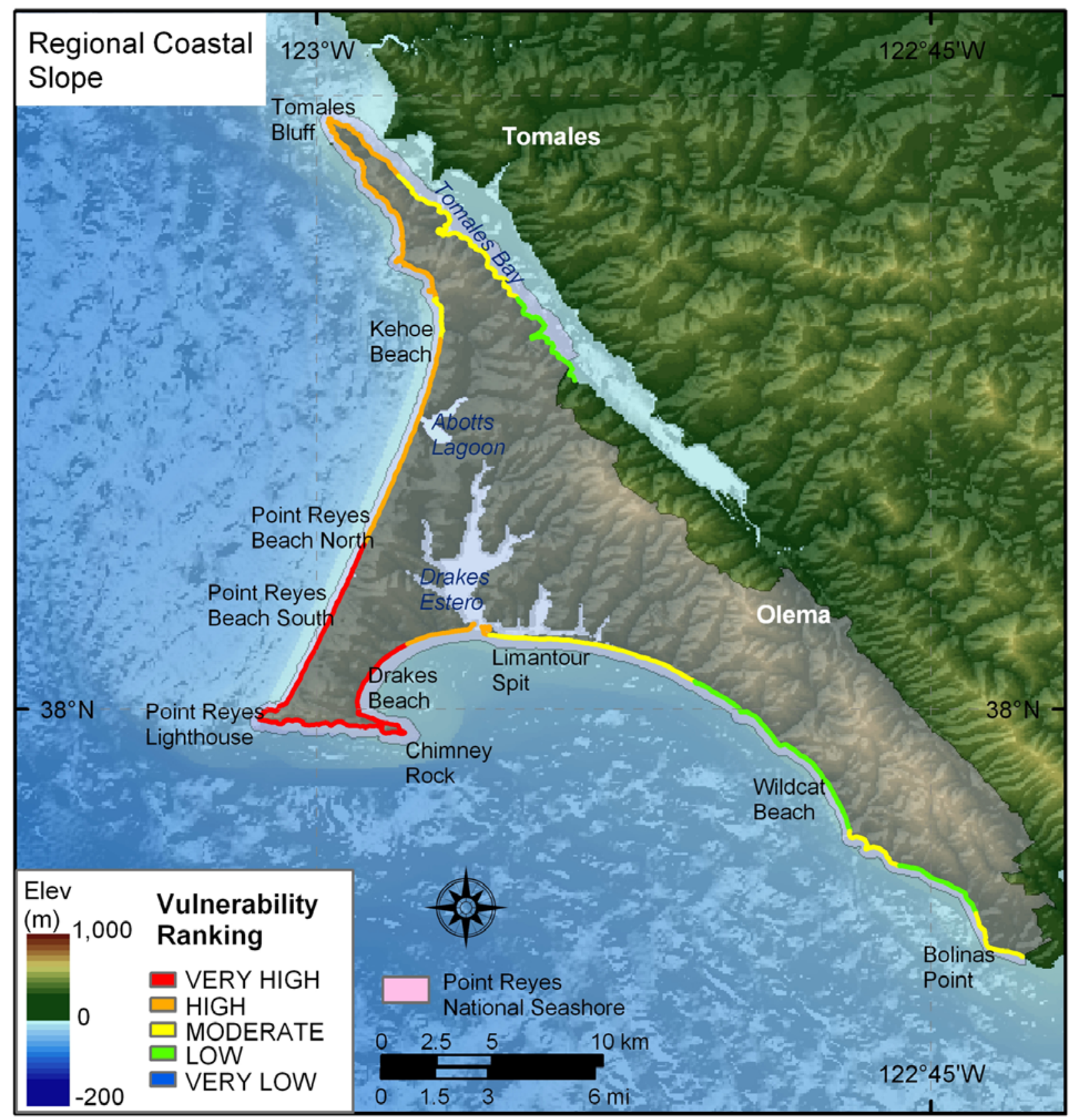

Figure 7. Regional coastal slope for Point Reyes National Seashore. The colored shoreline represents the vulnerability associated with the regional slope of the land, $10 \mathrm{~km}$ landward and seaward of the shoreline. The highest vulnerability slopes are generally Drakes Estero and points north and west. Lower vulnerability slopes are generally adjacent to the mainland or near the higher mountains to the south. 


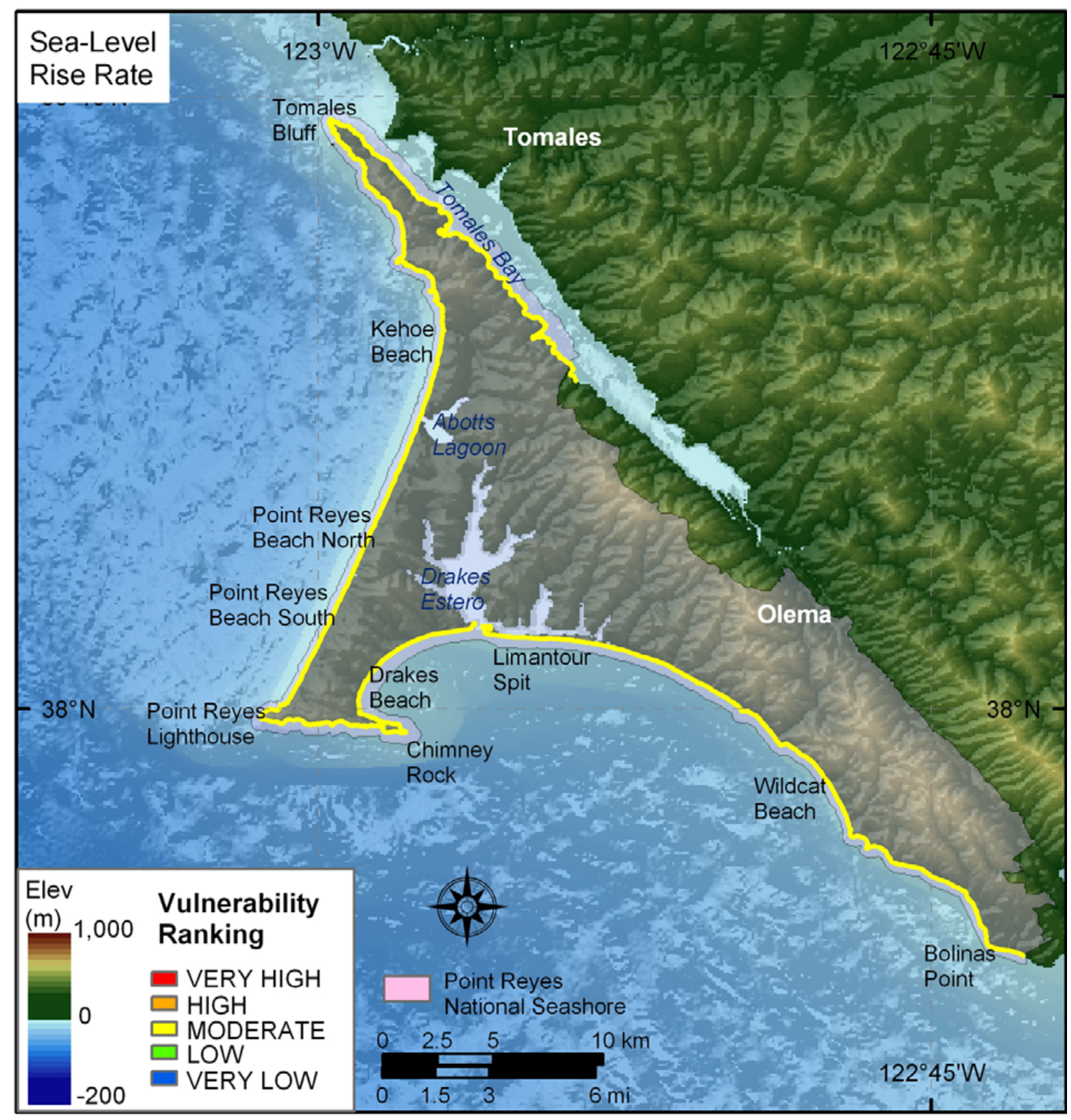

Figure 8. Rate of relative sea-level rise for Point Reyes National Seashore. The colored shoreline represents the vulnerability associated with the rate of sea-level rise for Point Reyes, CA. All of Point Reyes is ranked as moderate vulnerability with respect to relative sea-level rise. 


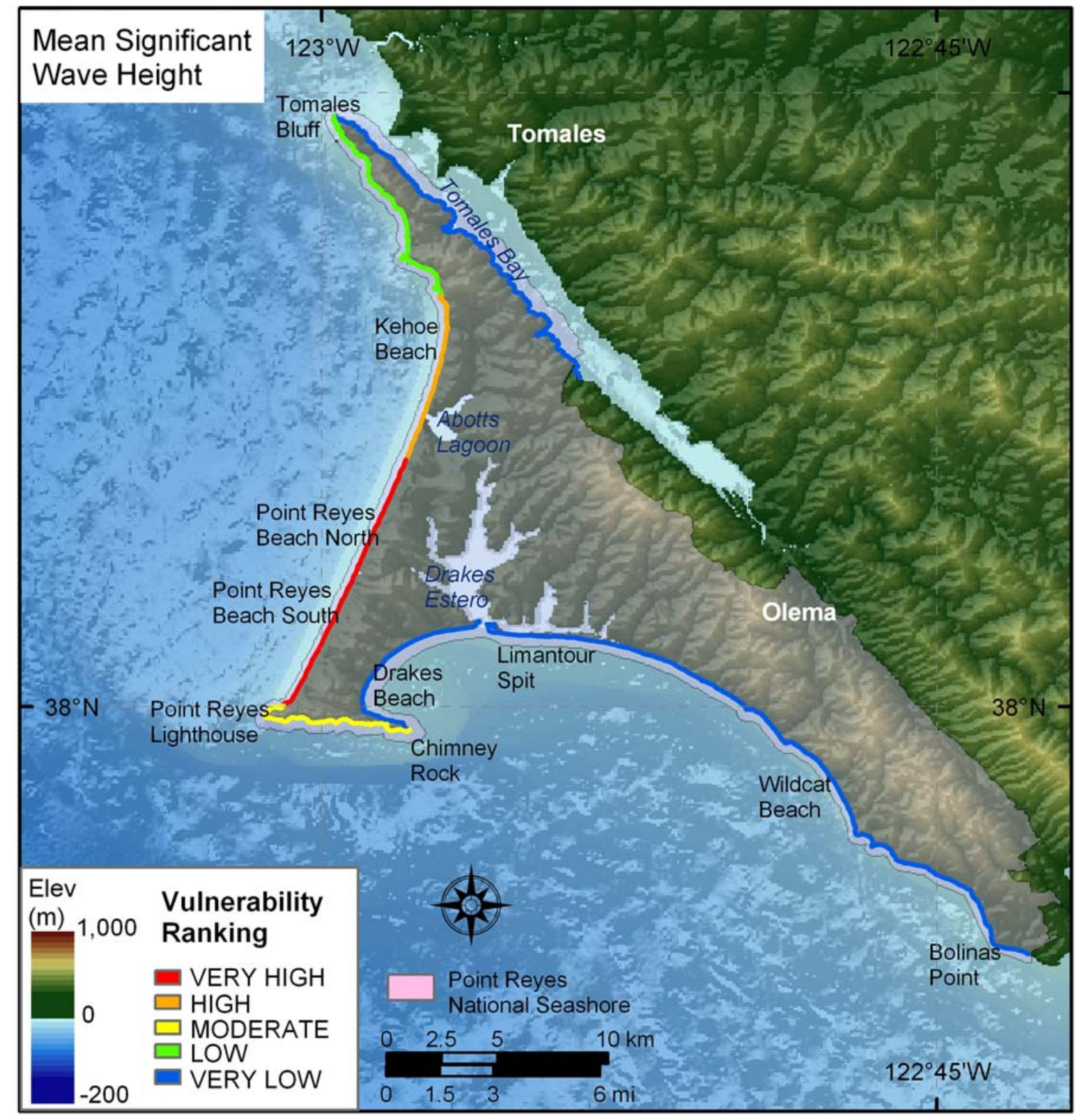

Figure 9. Mean Significant Wave Height for Point Reyes National Seashore. The colored shoreline represents the vulnerability associated with mean significant wave height within the park. Very High wave energy areas are located along the north side of Point Reyes where the dominant northwest waves approach. Wave heights are lowest in Tomales Bay and on the south side of Point Reyes. 


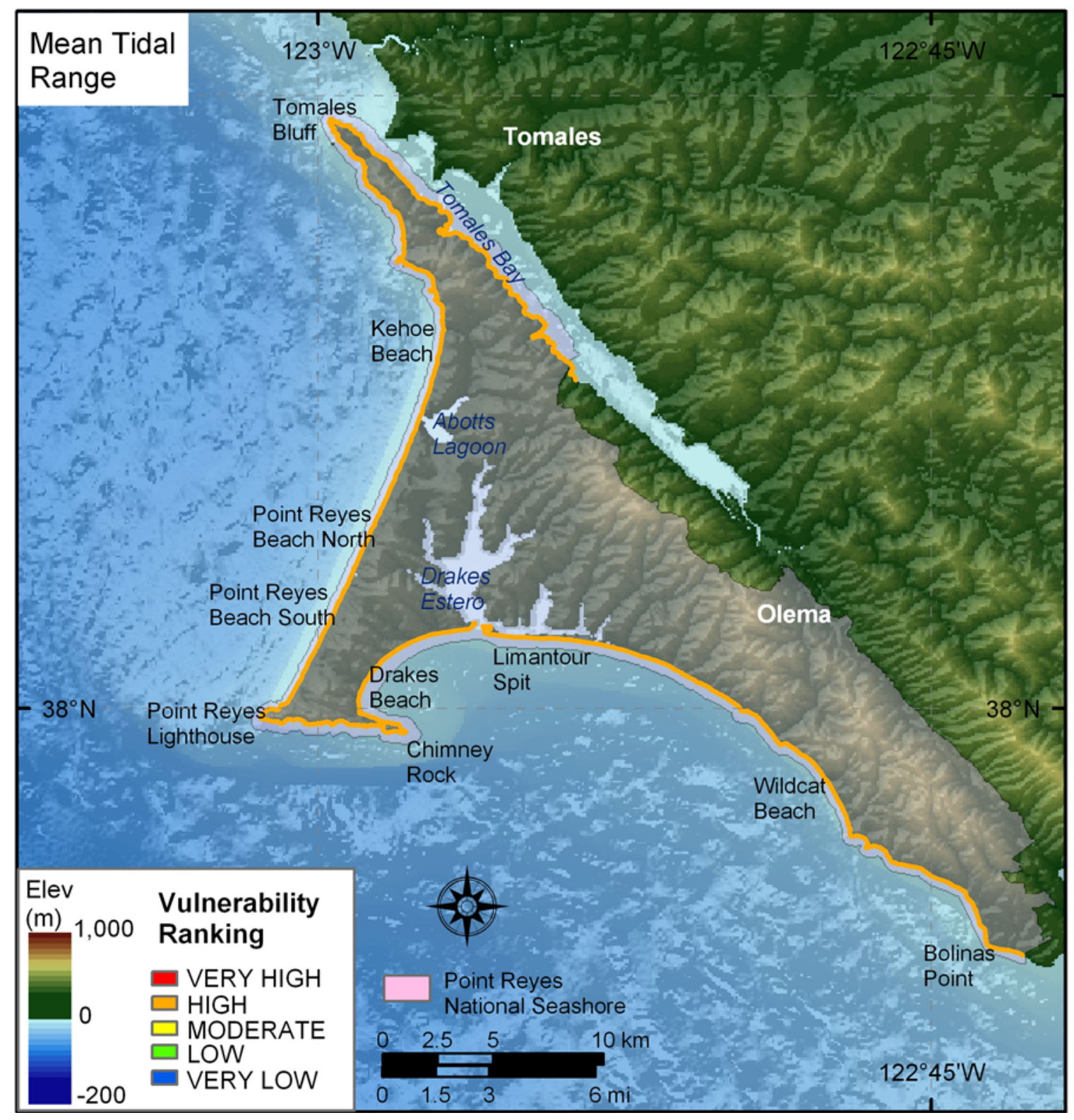

Figure 10: Mean Tidal Range for Point Reyes National Seashore. The colored shoreline represents the vulnerability associated with mean tidal range for Point Reyes. All of Point Reyes is ranked as high vulnerability with respect to tidal range. 


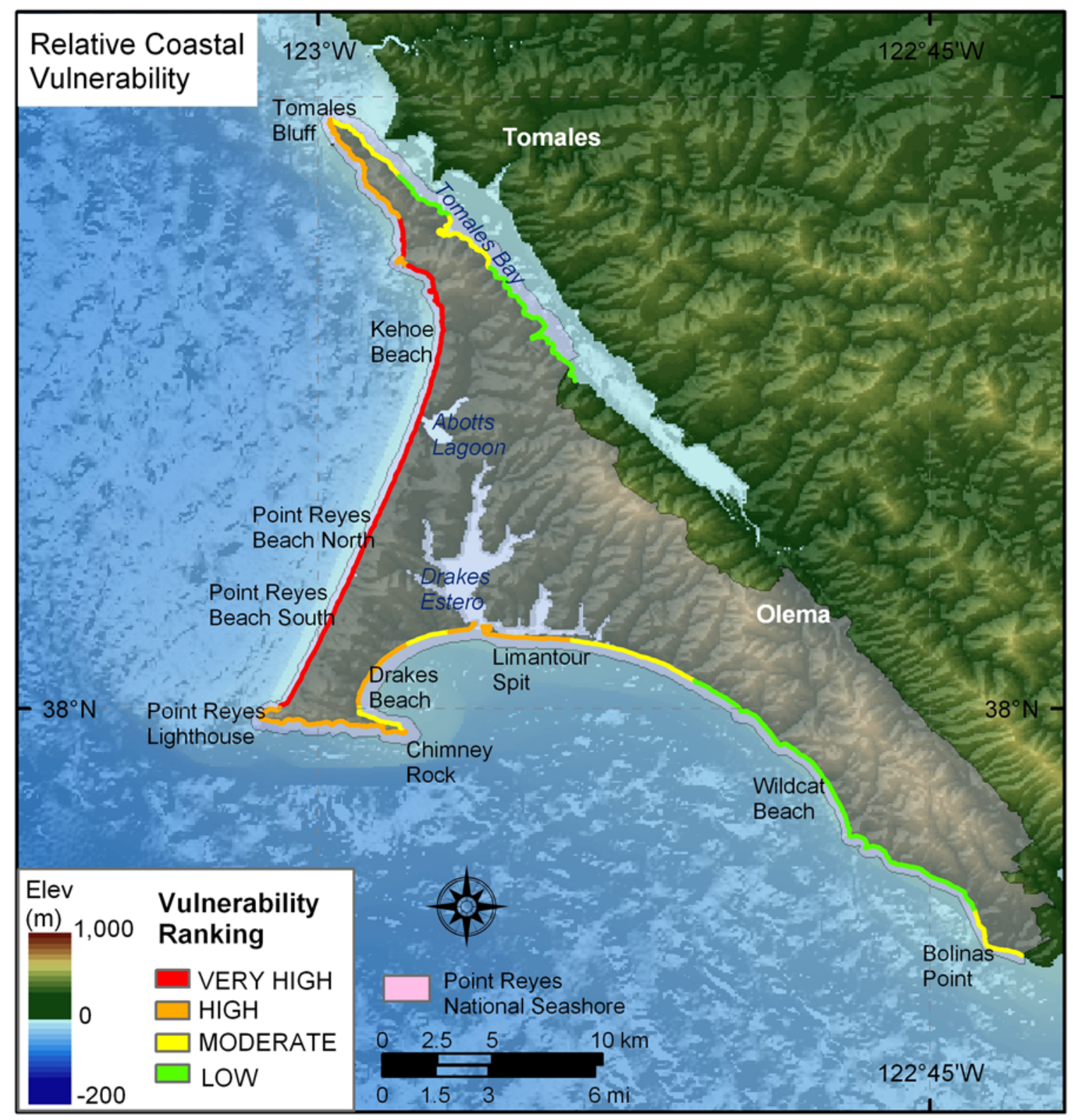

Figure 11: Relative Coastal Vulnerability for Point Reyes National Seashore. The colored shoreline represents the relative coastal vulnerability index $(\mathrm{CVI})$ determined from the six variables. The very high vulnerability shoreline is located along sandy beaches where significant wave heights are highest and regional coastal slope vulnerability is low. The lower vulnerability shoreline is located along rock cliffs where wave heights are lower and coastal slope is steep. 


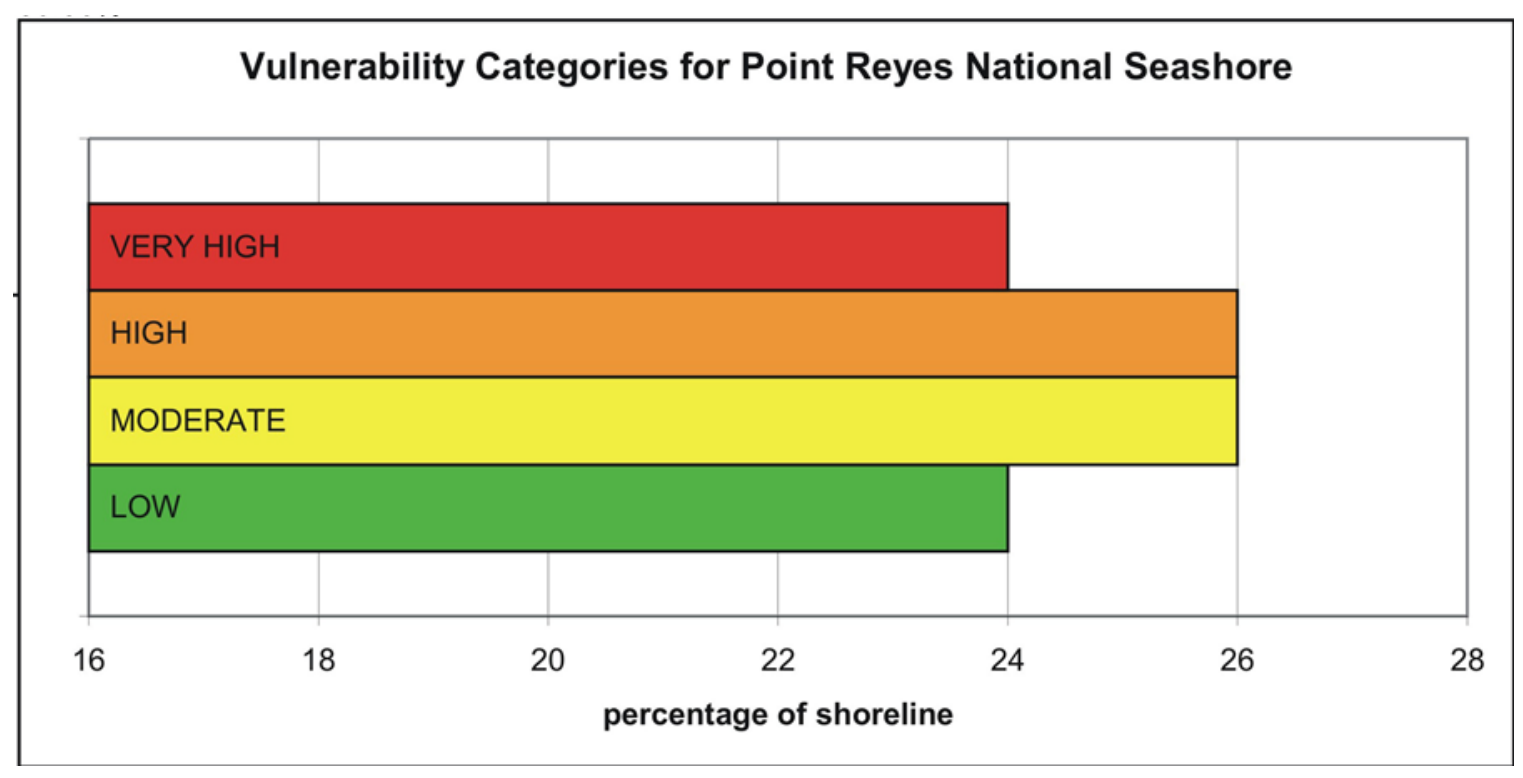

Figure 12: Percentage of Point Reyes shoreline in each CVI category. 
Table 1. Ranges for Vulnerability Ranking of Variables on the US Pacific Coast

\begin{tabular}{|c|c|c|c|c|c|}
\hline Variables & $\begin{array}{c}\text { Very Low } \\
1\end{array}$ & $\begin{array}{c}\text { Low } \\
2\end{array}$ & $\begin{array}{c}\text { Moderate } \\
3\end{array}$ & $\begin{array}{l}\text { High } \\
4\end{array}$ & $\begin{array}{l}\text { Very High } \\
5\end{array}$ \\
\hline GEOMORPHOLOGY & $\begin{array}{l}\text { Rocky } \\
\text { cliffed } \\
\text { coasts, } \\
\text { Fjords }\end{array}$ & $\begin{array}{l}\text { Medium } \\
\text { cliffs, } \\
\text { Indented } \\
\text { coasts }\end{array}$ & $\begin{array}{l}\text { Low cliffs, } \\
\text { Glacial drift, } \\
\text { Alluvial } \\
\text { plains }\end{array}$ & $\begin{array}{l}\text { Cobble Beaches, } \\
\text { Estuary, Lagoon }\end{array}$ & $\begin{array}{c}\text { Barrier beaches, Sand beaches, } \\
\text { Salt marsh, Mud flats, Deltas, } \\
\text { Coral reefs }\end{array}$ \\
\hline $\begin{array}{l}\text { SHORELINE EROSION/ } \\
\text { ACCRETION (m/yr) }\end{array}$ & $>2.0$ & $1.0-2.0$ & -1.0 to 1.0 & -2.0 to -1.0 & $<-2.0$ \\
\hline COASTAL SLOPE (\%) & $>14.70$ & $10.90-14.69$ & $7.75-10.89$ & $4.60-7.74$ & $<4.59$ \\
\hline $\begin{array}{l}\text { RELATIVE SEA-LEVEL } \\
\text { CHANGE (mm/yr) }\end{array}$ & $<1.8$ & $1.8-2.5$ & $2.5-3.0$ & $3.0-3.4$ & $>3.4$ \\
\hline $\begin{array}{l}\text { MEAN WAVE HEIGHT } \\
(\mathrm{m})\end{array}$ & $<1.1$ & $1.1-2.0$ & $2.01-2.25$ & $2.26-2.6$ & $>2.6$ \\
\hline MEAN TIDE RANGE (m) & $>6.0$ & $4.0-6.0$ & $2.0-4.0$ & $1.0-2.0$ & $<1.0$ \\
\hline
\end{tabular}


Table 2. Sources for Variable Data

\begin{tabular}{|c|c|c|}
\hline Variables & Source & $\begin{array}{c}\text { URL } \\
\text { (Not all sources are downloadable) }\end{array}$ \\
\hline GEOMORPHOLOGY & $\begin{array}{l}\text { An oblique aerial } \\
\text { photographic survey of } \\
\text { the California Coast }\end{array}$ & http://www.californiacoastline.org/ \\
\hline $\begin{array}{c}\text { SHORELINE } \\
\text { EROSION/ACCRETION } \\
(\mathrm{m} / \mathrm{yr})\end{array}$ & $\begin{array}{c}\text { Historical Shoreline } \\
\text { Change and Associated } \\
\text { Coastal Land Loss } \\
\text { Along the California } \\
\text { Coast, U.S. Geological } \\
\text { Survey (C.J. Hapke and } \\
\text { others, written } \\
\text { commun., 2004) }\end{array}$ & http://coastal.er.usgs.gov/shoreline-change/ \\
\hline COASTAL SLOPE (\%) & $\begin{array}{l}\text { NGDC Coastal Relief } \\
\quad \text { Model Vol } 07\end{array}$ & http://www.ngdc.noaa.gov/mgg/coastal/coastal.html \\
\hline $\begin{array}{l}\text { RELATIVE SEA-LEVEL } \\
\text { CHANGE }(\mathrm{mm} / \mathrm{yr})\end{array}$ & $\begin{array}{c}\text { NOAA Technical Report } \\
\text { NOS CO-OPS } 36 \text { SEA } \\
\text { LEVEL VARIATIONS } \\
\text { OF THE UNITED } \\
\text { STATES 1854-1999 } \\
\text { (Zervas, 2001) }\end{array}$ & http://www.co-ops.nos.noaa.gov/publications/techrpt36doc.pdf \\
\hline $\begin{array}{l}\text { MEAN WAVE HEIGHT } \\
(\mathrm{m})\end{array}$ & $\begin{array}{l}\text { Pacific Coast WIS Data } \\
\text { and National Data Buoy } \\
\text { Center }\end{array}$ & $\begin{array}{l}\text { http://frf.usace.army.mil/wis/wis_main.html } \\
\text { http://seaboard.ndbc.noaa.gov/ }\end{array}$ \\
\hline MEAN TIDE RANGE (m) & $\begin{array}{l}\text { NOAA/NOS CO-OPS } \\
\text { Historical Water Level } \\
\quad \text { Station Index }\end{array}$ & http://www.co-ops.nos.noaa.gov/usmap.html \\
\hline
\end{tabular}

